\title{
Generation (Wh) Y; The Digital Face of Pharmaceutical Education
}

\section{Voisey $\mathrm{CL}^{*}$}

School of Pharmacy, University of Keele, Staffordshire, UK

*Corresponding author: Carolyn Voisey, School of Pharmacy, Hornbeam Building, University of Keele, Keele, Staffordshire, ST5 5BG, UK, Tel: +44 01782 733876; Email: c.l.voisey@keele.ac.uk

\section{Review Article}

Volume 2 Issue 1

Received Date: March 26, 2018

Published Date: April 18, 2018

\section{Abstract}

The undergraduate population in pharmaceutical science is now more diverse than ever before, presenting considerable teaching challenges as educators are faced with increasing student numbers, lack of space availability and a desire to provide a more integrated approach to teaching and learning. Education technologies can play a pivotal role in engaging these technologically adept students but only when used in an effective and appropriate manner, however there is not as yet a consensus as to how effective these technologies might be in pharmaceutical sciences education.

Keywords: Education; Technology; Digital; Augmented reality; Virtual reality

Abbrevations: CAL: Computer Assisted Learning, VR: Virtual Reality, AR: Augmented Reality, 2D: 2Dimensional, PBL: Problem Based Learning, 3DVT: 3D Visualisation Technology.

\section{Introduction}

The undergraduate population in pharmaceutical science is now more diverse than ever before and the literature is full of studies trying to pigeon hole students into generations [1]. The most recent of these generations, those students born post-1980, have been termed the internet generation, generation $\mathrm{Y}$ and digital natives; while the concept of the 'digital native', defined as being an individual who have an innate confidence in using technology [2], may not accurately portray the technological capabilities of all students coming through higher education [3] it is still a useful idea to incorporate into teaching and learning. These students reportedly have different attitudes to their studies, different learning styles and patterns of behaviour to those who have gone before them [4-6]; they have the expectation that their studies should be meaningful [7] in a way that previous generations of students may not have done. It would seem that the days of students listening to didactic lectures while scribbling notes onto paper notepads are long gone.

\section{Technology and Active Learning}

Active learning strategies are featuring far more widely in HE, as teachers develop clearer understandings of how students prefer to learn and how they can work together to enhance that process; indeed Hyun, et al. [8] evaluated student satisfaction of their learning processes in an active learning classroom and found that this was significantly increased when compared to satisfaction measured in traditional classrooms [8]. Not only was that, but an increase in satisfaction with group learning noted in student's evaluations of their individual learning. Whether we believe in artificially grouping students into generations there is no doubt that the students born in the 80s and later have been surrounded by technology all 


\section{Open Access Journal of Pharmaceutical Research}

of their lives; however we would be foolish to assume that all these students are equally comfortable with using all forms of technology available to them $[9,10,6]$.

Technology in Higher Education is changing at a rapid rate; distance learning courses are able to take advantage of these developments to ensure that student interactivity with the tutors and their peers is enabled, leading to effective learning despite tutors and students possibly never actually meeting face to face [11,12]. This 'anytime, anyplace' learning isn't confined to distance learning courses however- in the 1990's the extent of learning technology was limited to email and online chat rooms/discussion boards (assuming you had a particularly forward thinking tutor); many courses in 2018 now utilise blogs, wikis and podcasts as part of their learning and teaching strategies [13]. Such methods of teaching and learning are used to great advantage in both individual and group course work, allowing students to interact with one another when they are off campus or over the vacation periods. Social networks are used not only for students to communicate socially but also to help build a community feel for the cohort; issues such as internet connection, students lack of familiarity with the technology however may limit the usefulness of social networks in this context [14].

\section{Advancement in Technologies}

Education technology appears to be more widespread in higher education than at school level, however with improvements in availability and affordability this may change moving forward. At a University level the majority of tutors are familiar with, and regularly make use of, technology such as power point, multimedia and simulation technology. More recently, student response systems (e.g. clickers) are being used in teaching sessions to gain the immediate feedback students appreciate, with the added benefit that the tutor can immediately see how well their students grasp the material [15]. Pharmaceutical science students may also have access to computer assisted learning (CAL) packages to help them understand the action of various drugs, pharmacokinetics etc., instead of carrying these experiments out in a traditional laboratory using animal tissue [16]. Although these technologies have been in use for many years, issues pertaining to decreased funding, increasing student numbers and the need to reduce, refine and replace the use of animals/animal tissues have ensured that these technologies are moving more into the spotlight.

The development of virtual reality (VR), augmented reality (AR) and 3D learning environments have added new and powerful tools to the range of educational technology available [17-19]. In both 2010 and 2011, the annual HORIZON report which discusses the emerging technologies likely to have a significant impact on teaching and learning in higher education, highlighted game-based learning and AR amongst other strategies for enhancing and improving education in the medical and medical science fields $[20,21]$. Students studying many of the pharmaceutical sciences are required to have a sound knowledge of the position of organs in the body (anatomy) and of their functions (physiology). This presents a teaching challenge as organs are 3-dimensional (3D) in nature; therefore their structure and connections to other body systems are not easily illustrated by 2dimensional (2D) graphics. Traditionally anatomy is taught through cadaver dissection, however with the increase in active learning such as CAL and problem based learning (PBL) the time available for dissection classes has become less and less. Add to this the ethical, emotional and availability issues that surround cadaver dissection and it becomes evident that alternative methods for teaching anatomy are required [22].

\section{The Power of 3D}

3D visualisation technology (3DVT) is of significant use in the physical sciences, such as chemistry, maths and engineering, with far fewer reports being found looking at this technology in the pharmaceutical and medical sciences limiting the literature available to evaluate the pedagogical effectiveness of 3DVT [23], although this is beginning to change. 3DVT is effective in the study of drug/receptor interactions [24], and an increasing body of evidence suggests that this technology has benefits for the pharmaceutical sciences and medicine [25,26]. Results are not clear-cut however; with some studies indicating that this technology has specific benefits, such as improvements in spatial ability) while not improving learning over all [27]. Two meta-analyses conducted in 2015 and 2016 each came to a different conclusion. One that 3DVT was effective in both the acquisition of factual anatomy and spatial anatomy knowledge [28], findings supported by the studies of Nicholson et al. [29], and Peterson and Mlynarczyk [26]. The second concluded that the use of 3D models could not be determined as superior to traditional teaching [30]. Evidently this is a field that requires further evaluation if the pedagogical effectiveness of 3DVT in pharmaceutical science education is to be fully understood.

\section{Summary}

Students engage better and improve their learning and problem solving abilities, when technology is used appropriately and in an effective manner [31-34]; just 


\section{Open Access Journal of Pharmaceutical Research}

because students are technologically savvy in their day to day lives does not mean that those skills automatically translate over to education technology. While the use of 3DVT has significant potential in the teaching of the pharmaceutical sciences, the evidence in the literature is still unclear as to its full benefits. This gap in knowledge must be closed if this technology is to be utilised in the most effective and appropriate manner, and to deliver the full benefits to those studying biological, medical or pharmaceutical sciences.

\section{References}

1. Dziuban C, Moskal P, Hartman J (2005) Higher education, blended learning, and the generations: Knowledge is power: No more. MA: Sloan Center for Online Education, pp: 1-17.

2. Prensky M (2001) Digital natives, digital immigrants. On the Horizon (MCB University Press) 9(5): 1-6.

3. Selwyn N (2009) The digital native - myth and reality. Aslib Proceedings 61(4): 364-379.

4. Boggs M, Szabo S (2011) Illuminating pathways through rigor, respect, relevance, and relationships: Scaffolding cross-generational understanding. Delta Kappa Gamma Bulletin: International Journal for Professional Educators 77(2): 27-34.

5. Twenge JM (2009) Generational changes and their impact in the classroom: teaching Generation Me. Med Educ 43 (5): 398-405.

6. Eckleberry Hunt J, Tucciarone J (2011) The Challenges and Opportunities of Teaching"Generation Y". J Grad Med Educ 3(4): 458-461.

7. Makinen M, Annala J, Linden J, Vilkka H (2014) Gen Y experiences of studying in higher education. Pp: 1-4.

8. Hyun J, Ediger R, Lee D (2017) Students' Satisfaction on Their Learning Process in Active Learning and Traditional Classrooms. International Journal of Teaching and Learning in Higher Education 29(1): 108-118.

9. Bennett SJ, Maton KA, Kervin LK (2008) The 'digital natives' debate: a critical review of the evidence. British Journal of Educational Technology 39(5): 775786.

10. Hargittai E (2010) Digital $\mathrm{Na}(\mathrm{t})$ ives? Variation in Internet Skills and Uses among Members of the "Net Generation". Sociological Inquiry 80(1): 92-113.
11. Beldarrain Y (2007) Distance Education Trends: Integrating new technologies to foster student interaction and collaboration. Distance Education 27(2): 139-153.

12. McIsaac MS, Gunawardena CN (1996) Distance education [Electronic version]. Jonassen DH (Eds.), In Handbook of research for educational communications and technology: A project of the Association for Educational Communications and Technology, New York: Simon \& Schuster Macmillan, pp: 403-437.

13. Weller M, Pegler C, Mason R (2005) Use of innovative technologies on an e-learning course. The Internet and Higher Education 8(1): 61-71.

14. Hsiu-Ting Hung, Steve Chi-Yin Yuen (2010) Educational use of social networking technology in higher education. Teaching in Higher Education 15(6): 703-714.

15. Kay RH, LeSage A (2009) Examining the benefits and challenges of using audience response systems: A review of the literature. Computers \& Education 53(3): 819-827.

16. Baby L, Kavalakkat J, Abraham S, Sathianarayanan S (2008) CAL: A Modern Tool for Pharmacology. The Internet Journal of Medical Simulation 2(2): 1-4.

17. Kamphuis C, Barsom E, Schijven M, Christoph N (2014) Augmented reality in medical education? Perspect Med Educ 3(4): 300-311.

18. Craig E, Georgieva M (2017) VR and AR: Driving a Revolution in Medical Education \& Patient Care.

19. Moro C, Štromberga Z, Raikos A, Stirling A (2017) The effectiveness of virtual and augmented reality in health sciences and medical anatomy. Anat Sci Educ 10(6): 549-559.

20. The New Media Consortium. The HORIZON report 2010 edition.

21. (2011) The New Media Consortium. The HORIZON report 2011(Edn).

22. Papa V, Vaccarezza M (2013) Teaching Anatomy in the XXI Century: New Aspects and Pitfalls. The Scientific World Journal 2013: 5.

23. Oloruntegbe K O, Alam GM (2010) Evaluation of 3D environments and virtual realities in science teaching and learning: The need to go beyond perception 


\section{Open Access Journal of Pharmaceutical Research}

referents. Scientific Research and Essays 5(9): 948954.

24. Richardson A, Bracegirdle L, McLachlan SI, Chapman SR (2013) Use of a Three-Dimensional Virtual Environment to Teach Drug-Receptor Interactions Am J Pharm Educ 77(1): 11.

25. Brazinaa D, Fojtikb R, Rombovac Z (2014) 3D visualization in teaching anatomy. Procedia Social and Behavioral Sciences 143: 367-371.

26. Peterson DC, Mlynarczyk GSA (2016) Analysis of traditional versus three-dimensional augmented curriculum on anatomical learning outcome measures. Anat Sci Educ 9(6): 529-536.

27. Hoyek N, Collet C, Di Rienzo F, De Almeida M, Guillot A (2014) Effectiveness of three- dimensional digital animation in teaching human anatomy in an authentic classroom context. Anat Sci Educ 7(6): 430-437.

28. Yammine K, Violato C (2015) A Meta-Analysis of the Educational Effectiveness of Three-Dimensional Visualization Technologies in Teaching Anatomy. Anat Sci Educ 8(6): 525-538.

29. Nicholson DT, Chalk C, Funnell WRJ, Daniel SJ (2006) Can virtual reality improve anatomy education? A randomised controlled study of a computergenerated three-dimensional anatomical ear model. Med Educ 40(11): 1081-1087.

30. Azer SA, Azer S (2016) 3D Anatomy Models and Impact on Learning: A Review of the Quality of the Literature. Health Professions Education 2(2):a80-98.

31. Trowbridge LW, Bybee RW, Powell JC (2008) Teaching secondary school science: Strategies for developing scientific literacy, 9th (Edn.), Upper Saddle River, NJ: Prentice Hall, pp: 362.

32. Blood E, Neel R (2008) Using student response systems in lecture-based instruction: Does it change student engagement and learning? Journal of Technology and Teacher Education 16(3): 375-383.

33. Guzey SS, Roehrig GH (2009) Teaching science with technology: Case studies of science teachers' development of technology, pedagogy, and content knowledge. Contemporary Issues in Technology and Teacher Education 9(1): 25-45.

34. Norris C, Sullivan T, Poirot J, Soloway E (2003) No access, no use, no impact: Snapshot surveys of educational technology in K-12. Journal of Research on Technology in Education 36(1): 15-27. 